$\begin{gathered}\text { Ana Dili Eğitimi Dergisi } \\ \text { Journal of Mother Tongue Education } \\ \text { www.anadiliegitimi.com }\end{gathered}$
Geliş/Received:02.10.2018 Kabul/Accepted:19.11.2018

\title{
Ortaokul Altıncı Sınıf Öğrencilerinin Sözcük Düzeyinde Yazım Yanlışlarının İncelenmesi
}

\section{Öz}

\author{
Özgür BABAYiĞiT*
}

Bu araştırmanın amacı, ortaokul altıncı sınıf öğrencilerinin sözcük düzeyinde yazım yanlışlarının incelenmesidir. Araştırma, nitel araştırma yöntemlerinden doküman incelemesi yöntemiyle gerçekleştirilmiştir. Kolay ulaşılabilir durum örneklemesi kapsamında Yozgat ili Merkez ilçedeki bir devlet ortaokulunda altıncı sınıfta öğrenim gören 163 öğrenci ile çalışıımıştır. Öğrencilerin 85’i erkek, 78'i kızdır. Veriler 2018 yılı mayıs ayında toplanmışır. Ortaokul altıncı sınıf öğrencilerine Türkçe derslerinde bir ders saati boyunca "aile sevgisi" konulu kompozisyon yazdırılmıştır. Elde edilen verilerin analizinde içerik analizi tekniği kullanılmışır. Yapılan araştırma neticesinde, ortaokul altıncı sınıf öğrencilerinin sözcük yazım yanlışları konusunda yedi adet sonuca ulaşılmıştır. Öğrencilerin sözcüğe fazladan harf ekleme, sözcükte harf eksikliği, sözcükteki harfi değiştirme, sözcükte hece eksikliği, sözcükte büyük ve küçük harfin bir arada kullanımı, ayrı yazılması gereken sözcüğü veya eki birleştirme, sözcükteki noktalı harflerin yazımında yanlışlık yaptıkları belirlenmiştir. Ortaokul altıncı sınıf öğrencilerinin konuşmadaki yanlışları yazıya aktardıkları belirlenmiştir. Sözcük yazım hatalarının azaltılmasına yönelik olarak, dikte çalışmalarının artıııması önerilmektedir. Bağlaç ve eklerin yazımındaki sıkıntılara yönelik olarak, yazım ve düzeltme çalışmalarının artıııması önerilmektedir. Öğrencilerin yazma çalışmaları sonrasında Türkçe öğretmeninin yazılı metinler üzerinde düzeltmeleri belirtmesi ve bu düzeltmelerin öğrencilere gösterilmesi gerekmektedir.

Anahtar Kelimeler: Ortaokul, sözcük, yazım yanlışı.

\section{Examining the Sixth Grade Students' Word-Level Spelling Mistakes}

\begin{abstract}
The aim of this study is to examine the word-level spelling mistakes of the sixth grade students in the secondary school. The research was carried out with the method of document analysis, one of the qualitative research methods. In the scope of convenience sampling, 163 students from the sixth grade were studied in a state secondary school in Yozgat. 85 of the students are male and 78 are female. Data were collected in May 2018. In the Turkish language lessons, the sixth grade students wrote a composition about family love. Content analysis technique was used in the analysis of the obtained data. As a result of the research, seven spelling mistakes on a word level were found which are; adding extra letters to the word, missing letters in a word, changing the letter in a word, lack of syllable in a word, use of the combination of upper and lower case in a word, merge of the word or the affix to be written separately, using incorrect dotted letters in a word. It was determined that the sixth grade students of the secondary school transferred the spoken language mistakes to writing. It is recommended to increase dictation studies in order to reduce word level writing mistakes. Additionally, it is recommended to increase feedback and correcting practices for the problems encountered in students' writings in using conjunctions and affixes. After the writing activities of the students, Turkish teachers should make corrections on the written texts and these corrections should be shown to the students.
\end{abstract}

Keywords: Secondary school, word, spelling mistake.

*Dr. Öğr. Üyesi, Yozgat Bozok Üniversitesi, Eğitim Fakültesi, Temel Eğitim Bölümü, Yozgat, ozgur.babayigit@ bozok.edu.tr, ORCID ID: 0000-0001-6123-0609 


\section{Giriş}

Illkokul birinci sınıftan itibaren bireylerin yazma becerilerinin geliştirilmesi amaçlanmaktadır. Yazma becerisinin gelişimi ile birlikte yazım yanlışlarının azalması öngörülmektedir. Araştırmanın giriş bölümünde sözcük ve yazım yanlışı konuları açıklanmıştır. Araştırmanın daha iyi anlaşılması bakımından öncelikle sözcük kavramının tanımlanmasında fayda bulunmaktadır. Sözcük, belirli bir anlamla birlikte kullanılan tek bir harf grubu anlamına gelmektedir (Mayor, 2009, s. 2019). Sözcük, anlamlı ses kombinasyonları ve anlam birimleri olarak tanımlanmaktadır (Johnson ve Johnson, 2005, s. 699). Sözcük, ifade etmek istediğimiz düşüncelerin, fikirlerin etiketidir (Akyol, 2006, s. 198). Sözcük, bir nesnenin anlamını işaret eden adıdır (Alperen, 2001, s. 39). TDK Güncel Türkçe Sözlüğe göre sözcük kavramı; anlamlı ses veya ses birliği, söz, sözcük olarak tanımlanmaktadır (TDK, 2018). Sözcük, ifade etmek istediğimiz düşüncelerin, tavırların göstergesidir (Özbay ve Melanlıoğlu, 2008, s. 32). Sözcük, anlamı veya görevi bulunan, çekim ekleri ile işlenmeye hazır tabandır (Kurudayıoğlu ve Karadağ, 2005, s. 305). Sözcük tanımları incelendiğinde, harf ve anlam konularının özellikle vurgulandığı görülmektedir.

Sözcük; ses açısından, vurgusu ve sözcük aralarını gösteren sinyallerle, yazımda aralarına konan boşluklarla birbirinden ayrılan ses birlikleridir. Biçim bilgisi açısından sözcük, kök veya gövde biçiminde çekim kalıplarının temelini oluşturmaktadır. Sözcük, anlamsal-sözlüksel açıdan sözlüklerde kodlanmış anlamın bağımsız en küçük taşıyıcısıdır. Söz dizimi açısından ise sözcük, cümlede yeri kaydırılabilen veya başkalarınca değiştirilebilen parçadır (Bussmann, 2002, s. 750). Dil bünyesinde bulunan sözcükler, herhangi bir nesnenin veya nesneler bütünün anlamını somut veya soyut olarak karşılamaktadır. Sözcükler, kavramların kimi zaman önemli bir parçası bazen de kendisi olmaktadır (Karatay, 2007, s. 142). Sözcük, seslerin ağızdan bir bütünleri olan heceler ile hecelerden oluşarak anlam yüklenen ses toplulukları olan sözcükler, dilin sistematiğini gösteren temel göstergelerdir (Göçer, 2015, s. 49). Sözcükler, düşüncedeki veya simgedeki varlık ve kavramların ses ve yazı olarak karşılıklarıdır. İnsan varlık ve kavramları hafızasına alırken bunların karşılığı olan simgeleri kullanmaktadır. Simgeler öncelikle ideogramları, yazının icadından sonra ise sözlü ve yazılı dilde sesleri, heceleri ve sözcükleri oluşturmuştur (Karatay, 2007, s. 142).

Sözcük kavramının ardından yazım yanlışı konusuna değinilmiştir. Yazım yanlışı, yazım kuralları ile ilgilidir. Yazım kuralları, bir dildeki sözcüklerin yazılış biçimlerini belirleyen kurallardır (TDK, 2018). Yazım kurallarını düzenleyen kitaplar yazım/imla kılavuzlarıdır (Beyreli, Çetindağ ve Celepoğlu, 2015, s. 18). Akyol (2013, s. 119) çok sayıda sözcüğün yanlış yazılması, sıklıkla dilbilgisi ve imla hatalarının yapılmasını, yazım sorunları içerisinde yer alan hafıza sorunları kavramı altında belirtmektedir. Öğrencinin yazım yanlışı yapmasının farklı sebepleri bulunmaktadır. Öğrenci sözcüğün doğru yazııışını daha önce hiç görmemiş olabilir. Sözcüğü yanlış öğrenmiş olabilir. Sözcüğün doğru 


\section{Ortaokul Altıncı Sınıf Öğrencilerinin Sözcük Düzeyinde Yazım Yanlışlarının İncelenmesi}

yazımı unutulmuş olabilir. Bu durumun ana nedeni ise yazma ve okuma eksikliğidir (Aktaş ve Gündüz, 2002, s. 115). Yazım yanlışları ile dolu bir yazı, yazarının eğitimsizliğini ele vermekte, daha da önemlisi ana diline gereken saygıyı göstermediği anlamına gelmektedir (Aktaş ve Gündüz, 2002, s. 115). Temple ve Gillet (1989, s. 416) yazım yanlışı yapılan sözcüklerin doğru olarak öğrenilmesi için şunları önermektedir:

1. Sözcüğün içindeki harflerin doğru sırasını çalışın, yazımı tekrarlayın.

2. Gözlerinizi kapatın ve yazımı kendiniz tekrarladığınız için aklınızdaki sözcüğü resimleyin.

3. Gözlerinizi açın ve tekrar sözcüğe bakın, harflerin sırasını tekrarlayın.

4. Hem yanlış yazılan sözcüğü hem de düzeltmeyi örtün ve sözcüğü hafızadan yazın.

5. Son olarak, sözcüğü doğru yazıp yazmadığınızı kontrol edin. Değilse, bu beş adımı tekrarlayın.

Konu ile ilgili olarak yapılan araştırmalar incelendiğinde, Kurtlu ve Korucu (2015) tarafından yapılan çalışma dikkat çekmektedir. Araştırma sonucunda, noktalama işaretlerini kullanma ve imla kurallarını uygulama bakımından bitişik eğik yazı ve düz dik temel yazı arasında kesin bir çizgi çizmenin ve bir yargıya varmanın doğru olmayacağı söylenebilmektedir. Noktalama işaretleri ve imla kurallarıyla ilgili bitişik eğik yazıda daha az hata yapıldığı, düz dik temel yazıda daha fazla sözcük kullanıldığı, her iki yazı türünde de yapılan hataların birbirine benzediği, bitişik eğik yazıda sözcüklerin, dik düz yazıda ise harflerin yanlış yazıldığı belirlenmiştir. Calp (2013) tarafından yapılan araştırma sonucunda, öğrencinin başlangıçta 27 olan yazma hata sayısı 9'a inmiştir. Öğrencinin yazısı okunabilirlik açısından kabul edilebilir düzeye gelmiştir. Akkaya (2013) tarafından yapılan araştırma sonucunda, öğrencilerin sınavlarda simgeleri, kısaltmaları, düzeltme işaretini, yabancı özel adları kullanmadığı; ek fiilin yazııışı ve fiil çekimiyle ilgili yanlış yapmadıkları; ünlü daralması ve ünlü türemesi ses olaylarının olduğu sözcükleri doğru yazdıkları görülmüştür. Altıncı sınıf öğrencilerinin en fazla büyük harflerin yazılışında yanlış yaptıkları tespit edilmiştir. Bununla birlikte sessiz harflerin yazılışı, sesli harflerin yazıışı, ses yutumu, bağlaç olan da, de'nin yazılışı ise en fazla tekrarlanan diğer yazım yanlışlarıdır. Türkçe öğretmenleri, altıncı sınıf öğrencilerinin yazım yanlışlarının nedenlerinin ilgi ve dikkat eksikliğinden, temel dil becerilerini edinemediklerinden, okul dışında Türkçe'nin doğru, güzel ve etkili kullanılmamasından, sınav türlerinden ya da öğretmenlerin sınav değerlendirmelerinden ve öğretmenlerin ya da öğrencilerin yazım kurallarının kaynaklarından etkili bir şekilde yararlanmadıklarından kaynaklandığını ifade etmiştir. Hamzadayı ve Çetinkaya (2013) tarafından yapılan araştırmanın amacı, öğrencilerin bilgi düzeyindeki yazım ve noktalama işaretleri ile ilgili davranışlarını uygulama düzeyine çıkarabilmelerinde dikte yönteminin etkili olup olmadığını sorgulamaktır. Araştırma, Gaziantep ili Vali Lütfullah Bilgin IIlköğretim Okulu’nda öğrenim görmekte 
olan beşinci sınıf düzeyindeki 23 öğrenci araştırma kapsamına alınmıştır. Araştırmadan elde edilen veriler, öğrencilerin yazım kurallarını uygulama sürecinde yapmış oldukları yanlışlar açısından önuygulama ve son uygulamaları arasında son uygulama lehine toplamda \% 64,3'lük bir düzelme gerçekleştiğini ortaya koymaktadır. İlanbey ve Can (2016) tarafından yapılan araştırma sonucunda internet dili kullanımı, argo kullanımı, az çaba kuralı, konuştuğu gibi yazma, ağız kullanımı yazım yanlışıkları belirlenmiştir.

Yapılan bu araştırmanın amacı, ortaokul altıncı sınıf öğrencilerinin sözcük yazım yanlışlarının incelenmesidir. Araştırma, ortaokul altıncı sınıf öğrencilerinin yaptıkları yazım yanlışlarının belirlenmesi, nedenlerinin ortaya koyulması açısından önemlidir. Araştırmanın öncelikle Türkçe öğretmenlerine, genelde Türkçe öğretimi alanında özelde ise yazma eğitimi alanında çalışan araştırmacılara katkı sağlayacağı düşünülmektedir.

\section{Yöntem}

\section{Araştırmanın Modeli}

Araştırma, nitel araştırma yöntemlerinden doküman incelemesi yöntemiyle gerçekleştirilmiştir. Doküman incelemesi, yazılı veya görsel malzemenin toplanıp incelenmesidir (Sönmez ve Alacapınar, 2011, s. 83). Doküman incelemesi, araştırılması hedeflenen olgu veya olgular hakkında bilgi içeren materyallerin analizini kapsamaktadır (Yıldırım ve Şimşek, 2006, s. 187). Ortaokul altıncı sınıf öğrencilerinin sözcük yazım yanlışlarını incelemek amacıyla öğrenci yazıları incelendiğinden, doküman incelemesi yöntemi kullanılmıştır.

\section{Araştırma grubu}

Çalışma grubunun belirlemesinde, amaçlı örnekleme yöntemlerinden kolay ulaşılabilir durum örneklemesi kullanılmıştır. Kolay ulaşılabilir durum örneklemesi yöntemi, araştırmaya hız ve pratiklik kazandırmaktadır (Patton, 2014, s. 242; Yıldırım ve Şimşek, 2006, s. 113;). Öncelikle Yozgat il Milli Eğitim Müdürlüğünden gerekli izinler alınmıştır. Kolay ulaşılabilir durum örneklemesi kapsamında Yozgat ili Merkez ilçedeki bir devlet ortaokulunda altıncı sınıfta öğrenim gören 163 öğrenci ile çalışımıştır. Öğrencilerin tamamı normal zekâ seviyesine sahip olup, özel eğitim kurslarına devam eden öğrenci bulunmamaktadır. Öğrencilerin 85’i erkek, $78^{\prime}$ i kızdır.

\section{Veri Toplama Araçları}

Araştırmanın planlanması aşamasında, Türkçe öğretimi alanında uzman bir doktor öğretim üyesiyle görüş alışverişinde bulunulmuştur. Uzman öğretim üyesiyle ortak fikir sonucunda, ortaokul altıncı sınıf öğrencilerine kompozisyon yazdırımasına karar verilmiştir. Kompozisyon yazdırılmasına karar verilmesinin ardından, Türkçe öğretmenliği alanında doktora öğrenimi gören ve aynı zamanda 


\section{Ortaokul Altıncı Sınıf Öğrencilerinin Sözcük Düzeyinde Yazım Yanlışlarının İncelenmesi}

Türkçe öğretmeni olarak ortaokulda görev yapan alan uzmanı ile araştırma paylaşılmıştır. Türkçe öğretmeniyle yapılan görüşme sonrasında kompozisyon konusunun "aile sevgisi" olmasına karar verilmiştir. Kompozisyon konusu belirlenirken, öğrencilerin kolaylıkla yazabilecekleri bir kompozisyon konusu belirlenmek istenmiştir. Bilimsel bilgi ve kavramların fazlaca yer almadığı bir konu tespiti amaçlanmıştır. Bu nedenle öğrencilerin yakın çevresinden, gündelik yaşamlarından bir konunun olmasına karar verilmiştir. Daha sonra aile konusu belirlenmiştir. Aile konusunun çok geniş ve kapsamlı olması nedeniyle konunun daraltılması gerektiği düşünülmüştür. Bu nedenle "aile sevgisi" konusuna karar verilmiştir.

\section{Verilerin Toplanması}

Veriler 07-11 Mayıs 2018 tarihleri arasında, beş günlük bir sürede toplanmıştır. Araştırmacı, Türkçe öğretmeni ile birlikte veri toplama aşamasında bulunmuştur. Türkçe derslerinin başlangıcında, Türkçe öğretmeni araştırmacıyı öğrencilere tanıtmıştır. Araştırma hakkında öğrencilere kısaca bilgi verilmiştir. Ortaokul altıncı sınıf öğrencilerine Türkçe derslerinde bir ders saati boyunca "aile sevgisi" konulu kompozisyon yazdırılmıştır. Öğrencilere kompozisyon yazdırma görevi Türkçe öğretmeninde olmuştur. Araştırmacı kâğıtların dağıtılması ve toplanması işlerini yürütmüştür. Bu araştırma aile konusundaki sözcüklerin yazımı ile sınırlıdır. Altı şubede öğrenim gören toplam 163 öğrenci ile çalışılmıştır.

\section{Verilerin Analizi}

Elde edilen verilerin analizinde içerik analizi tekniği kullanılmıştır. İçerik analizinde veriler kodlandıktan sonra, veriler içinde tema ve örüntüler aramak için analitik tekniklere başvurulmaktadır (Glesne, 2012, s. 255). Öğrencilerin sözcük yazım yanlışları incelendikten sonra, belirli kodlar, kategoriler ve temalar altında gruplandırılmıştır (Creswell, 2012, s. 243).

Yapılan bu nitel araştırmada geçerliliği sağlamak için kod ve temaların uzman tarafından incelemesi yöntemi işe koşulmuştur. Uzman kişi, Türkçe öğretimi alanında çalışan öğretim üyesidir. Araştırmanın güvenirliği boyutunda, araştırmacı tarafından planlananlar ile gerçekleştirilenler, eğitimde ölçme ve değerlendirme alanında doktora yapmış bir öğretim üyesi ile sürecin planlanmasından sonuna kadar paylaşılmıştır. Nitel araştırmaların geçerlik ve güvenirliği boyutu büyük ölçüde araştırmacının etik ilkelere bağlılığıyla yakından ilişkilidir (Merriam, 2013, s. 220). Bu nedenle araştırmada Creswell (2013, s. 92-101) tarafından belirtilen etik kurallar araştırmacı tarafından yerine getirilmiştir.

Verilerin içerik analizi sürecinde, araştırmacı tarafından ve Türkçe öğretimi alanında uzman öğretim üyesi tarafından ikinci kodlamacı olarak kodlamalar yapılmıştır. Araştırma sürecinde öğrencilerden elde edilen yazılarda kodlama birimi olarak sözcük seçilmiştir. Araştırma amacının 
sözcük seviyesinde yazım yanlışları olması nedeniyle sadece sözcük boyutunda inceleme yapılmıştır. Veri analizinde Çelik ve Ekşi (2015, s. 47) tarafından belirtildiği üzere, öncelikle açık kodlama, ikinci olarak eksen kodlama, üçüncü ve son olarak seçici kodlama gerçekleştirilmiştir. Yapılan içerik analizi sürecinde ulaşılan kodlar, kategoriler ve temalar Tablo 1'de sunulmaktadır.

Tablo 1. Içerik analizi sonucu ulaşılan kodlar, kategoriler ve temalar

\begin{tabular}{|c|c|c|}
\hline Ulaşılan kodlar & Kodlardan ulaşılan kategoriler & Kategorilerden ulaşılan temalar \\
\hline $\begin{array}{l}\bullet \text { Harf } \\
\bullet \text { Ekleme } \\
\text {-Fazlalık } \\
\text {-Fazla harf }\end{array}$ & $\begin{array}{l}\text {-Harf ekleme } \\
\text { •Fazla harf }\end{array}$ & •Sözcüğe fazladan harf ekleme \\
\hline $\begin{array}{l}\text {-Eksiklik } \\
\text {-Harf } \\
\text {-Sesli } \\
\text {-Sessiz }\end{array}$ & $\begin{array}{l}\bullet \text { Harf unutma } \\
\bullet \text { Harf eksikliği }\end{array}$ & •Sözcükte harf eksikliği \\
\hline $\begin{array}{l}\text {-Harf } \\
\text {-Değiştirme } \\
\text {-Yumuşama } \\
\text {-Sertleşme }\end{array}$ & $\begin{array}{l}\text { •Harf değiştirme } \\
\text { •Ünsüz uyumu }\end{array}$ & •Sözcükteki harfi değiştirme \\
\hline $\begin{array}{l}\bullet \text { Hece } \\
\bullet \text { Eksiklik } \\
\bullet \text { Hece atlama } \\
\end{array}$ & $\begin{array}{l}\bullet \text { Hece unutma } \\
\bullet \text { Hece atlama }\end{array}$ & •Sözcükte hece eksikliği \\
\hline $\begin{array}{l}\text { •Büyük harf } \\
\text { •Küçük harf } \\
\text { •Küçük harf yerine büyük harf } \\
\text { •Büyük harf yerine küçük harf }\end{array}$ & •Büyük ve küçük harfi karıştırma & $\begin{array}{l}\text { •Sözcükte büyük ve küçük harfin } \\
\text { bir arada kullanımı }\end{array}$ \\
\hline $\begin{array}{l}\text { •Birleşik sözcük } \\
\text { •Ayrı sözcükler } \\
\text { •Ek } \\
\text { •Bağlaç }\end{array}$ & $\begin{array}{l}\text {-Ayrı sözcüklerin yazımı } \\
\text { •Bağlaçlar } \\
\text { •Ekler }\end{array}$ & $\begin{array}{l}\text { •Ayrı yazılması gereken sözcüğü } \\
\text { veya eki birleştirme }\end{array}$ \\
\hline $\begin{array}{l}\text {-Sesli harfler } \\
\text {-Ğ harfi } \\
\text {-Harf noktası }\end{array}$ & $\begin{array}{l}\text {-Noktalı harfler } \\
\text { •Şapkalı harfler }\end{array}$ & $\begin{array}{l}\text { •Sözcükteki noktalı harflerin } \\
\text { yazımında yanlışlık }\end{array}$ \\
\hline
\end{tabular}

Verilerinin analizinin güvenirliği için Miles ve Huberman (2015, s. 64) tarafından geliştirilen güvenirlik formülü [Güvenirlik=Görüş birliği sayısı / (Toplam görüş birliği + Görüş ayrılığı sayısı)] temel alınmıştır. Bu analize göre, güvenirlik katsayısı=.91 olarak hesaplanmıştır. Bu bulguya göre kodlamaların güvenilir olduğu söylenebilir. Veriler, ilgili temalara göre okuyucunun kolayca anlayabileceği bir yapıda bulgular bölümünde verilmiştir. 


\section{Ortaokul Altıncı Sınıf Öğrencilerinin Sözcük Düzeyinde Yazım Yanlışlarının İncelenmesi}

\section{Bulgular}

Yapılan içerik analizi sonucunda yedi adet temaya ulaşılmıştır. Ulaşılan temalar Şekil 1'de görülmektedir.

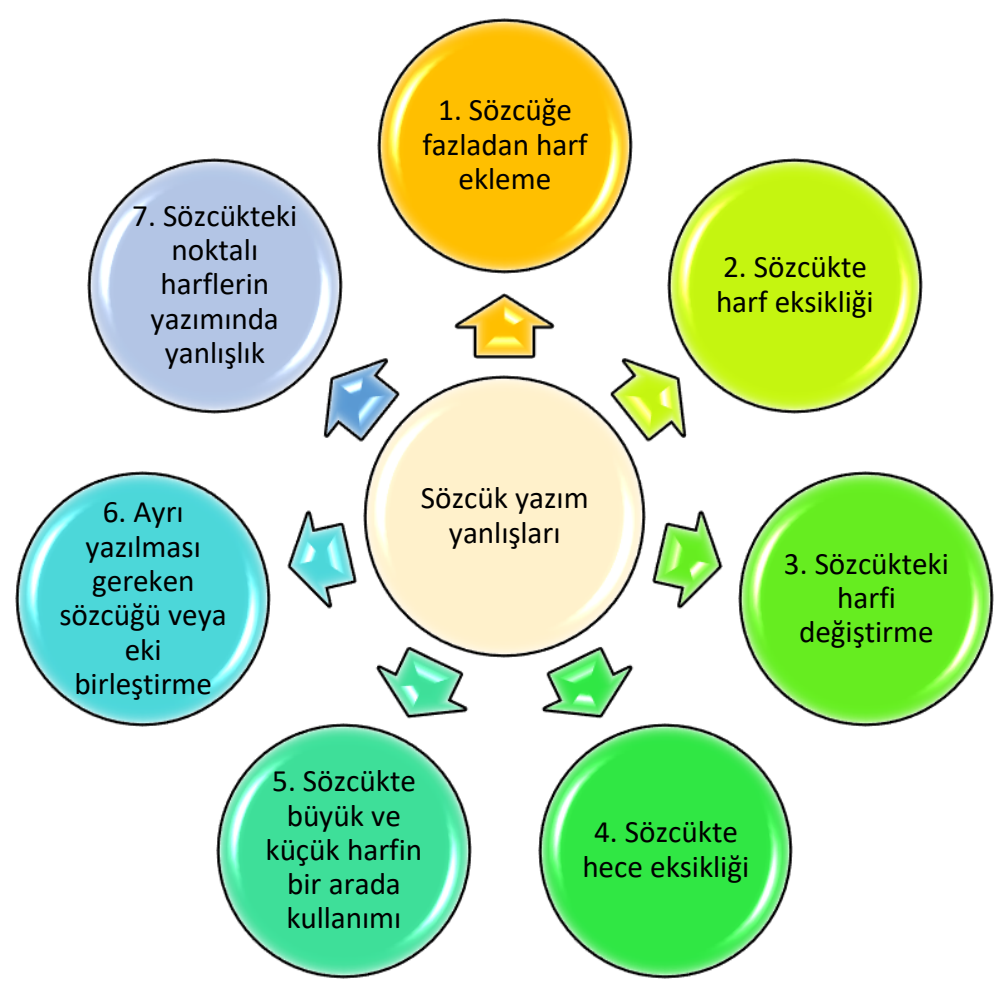

Şekil 1. Sözcük yazım yanlışları

Şekil 1 incelendiğinde ulaşılan sözcük yazım yanlışlığı temaları görülmektedir. Bulgular Şekil $1^{\prime}$ de belirtilen temalar altında sunulmaktadır.

\section{Tema 1. Sözcüğe Fazladan Harf Ekleme}

Ulaşılan ilk tema sözcüğe fazladan harf ekleme temasıdır. Bu tema kapsamına ortaokul altıncı sınıf öğrencilerinin sözcüklere fazladan harf eklediği tespit edilmiştir. Konu ile ilgili olarak örnek bir öğrenci kompozisyonu Resim 1'de görülmektedir. 


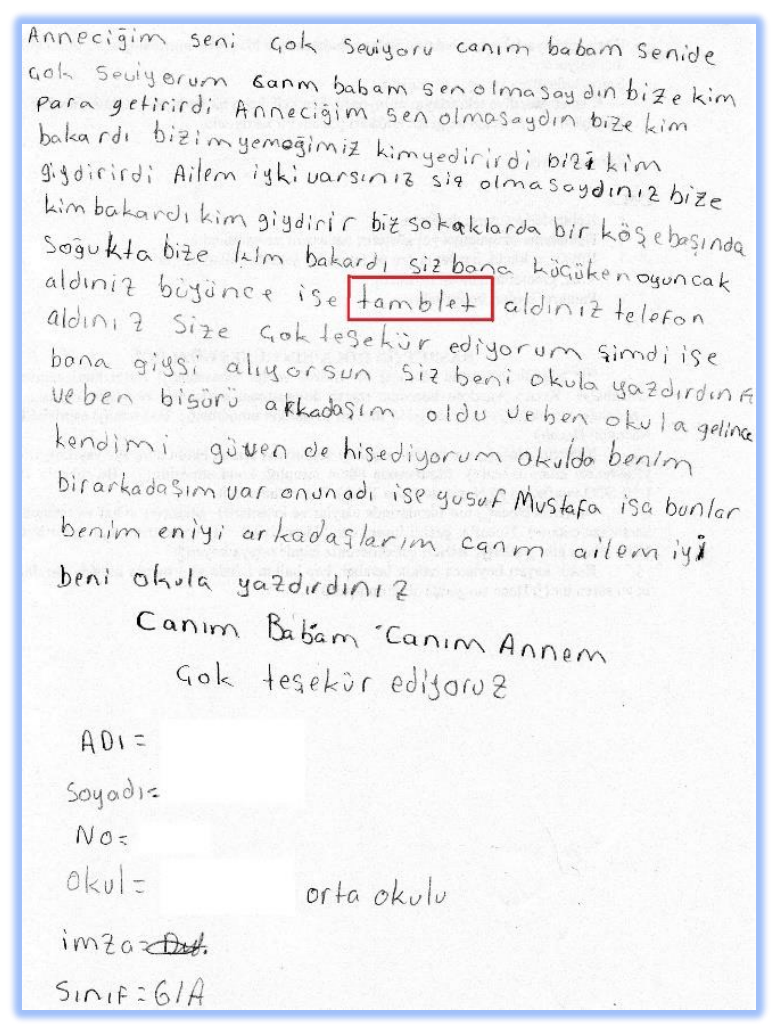

Resim 1. Öğrenci kompozisyonu

Resim 1'deki öğrenci kompozisyonunda, kırmızı dikdörtgen içinde kalan bölümde "tamblet" yazıldığı görülmektedir. Tema kapsamında ulaşılan sözcük yazım yanlışları Tablo 2'de sunulmaktadır.

Tablo 2. Sözcüğe fazladan harf ekleme

\begin{tabular}{ll}
\hline Sözcük yanlış yazımı & Sözcük doğru yazımı \\
\hline tamblet & tablet \\
anlaşamayı & anlaşmayı \\
amma & ama \\
teşşekür & teşekkür \\
\hline
\end{tabular}

Tablo 2'de sözcüğe fazladan harf ekleme yanlışları görülmektedir. Bu sözcük yazım yanlışları incelendiğinde sözcük yazımlarında fazladan bir harf eklendiği görülmektedir.

\section{Tema 2. Sözcükte Harf Eksikliği}

Ulaşılan ikinci tema sözcükte harf eksikliği temasıdır. Bu tema kapsamına ortaokul altıncı sınıf öğrencilerinin sözcükte bir harfi eksik yazdığı tespit edilmiştir. Konu ile ilgili olarak örnek bir öğrenci kompozisyonu Resim 2'de görülmektedir. 


\section{Ortaokul Altıncı Sınıf Öğrencilerinin Sözcük Düzeyinde Yazım Yanlışlarının İncelenmesi}

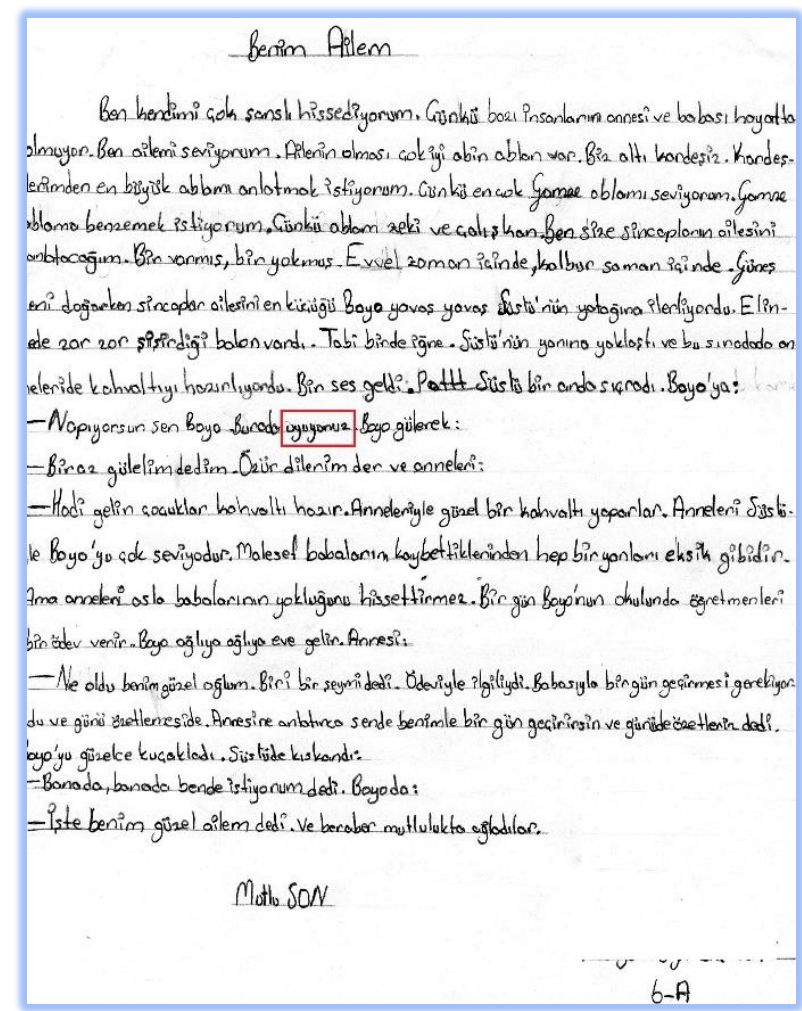

\section{Resim 2. Öğrenci kompozisyonu}

Resim 2'de yer alan örnek öğrenci kompozisyonunda, kırmızı dikdörtgen ile işaretlenen yerde, "uyuyonuz" şeklinde yazıldığı görülmektedir. Tema kapsamında ulaşılan sözcük yazım yanlışları Tablo 3'te sunulmaktadır.

Tablo 3. Sözcükte harf eksikliği

\begin{tabular}{ll}
\hline Sözcük yanlış yazımı & Sözcük doğru yazımı \\
\hline ale & aile \\
olu & oğlu \\
dakka & dakika \\
semez & sevmez \\
semedin & sevmedin \\
sağlalar & sağlarlar \\
bide & birde \\
anemin & annemin \\
bi & bir \\
seviyoru & seviyorum \\
canm & canım \\
kodu & koydu \\
heycanla & heyecanla \\
küçüken & küçükken \\
göstedin & gösterdin \\
kızıyo & kızıyor \\
teşekür & teşekkür \\
seviyolar & seviyorlar \\
kahkaa & kahkaha \\
getiriyolar & getiriyorlar \\
hisediyorum & hissediyorum \\
teşşekür & teşekkür \\
\hline
\end{tabular}


Tablo 3’te sözcükte harf eksikliği yanlışları görülmektedir. Bu sözcük yazım yanlışları incelendiğinde sözcük yazımlarında bir harfin eksik olarak yazıldığı görülmektedir. Öğrenci yazıları incelendiğinde şöyle bir durum tespit edilmiştir. Aynı öğrenci bir cümlede "canm" olarak yanlış yazdığı bir sözcüğü, farklı bir cümlesinde "canım" olarak doğru bir şekilde yazmaktadır. Bu yazım yanlışları incelendiğinde, konuşma sırasında sözcüklerde eksik harf söyleme durumu akla gelmektedir. Örneğin konuşmada kullanılan “dakka” sözcüğünün yazıya aynen geçirildiği düşünülmektedir.

\section{Tema 3. Sözcükteki Harfi Değiştirme}

Ulaşılan üçüncü tema sözcükteki harfi değiştirme temasıdır. Bu tema kapsamına ortaokul altıncı sınıf öğrencilerinin sözcükte yer alan bir harfi, başka bir harfle yazdığı tespit edilmiştir. Konu ile ilgili olarak örnek bir öğrenci kompozisyonu Resim 3'te görülmektedir.

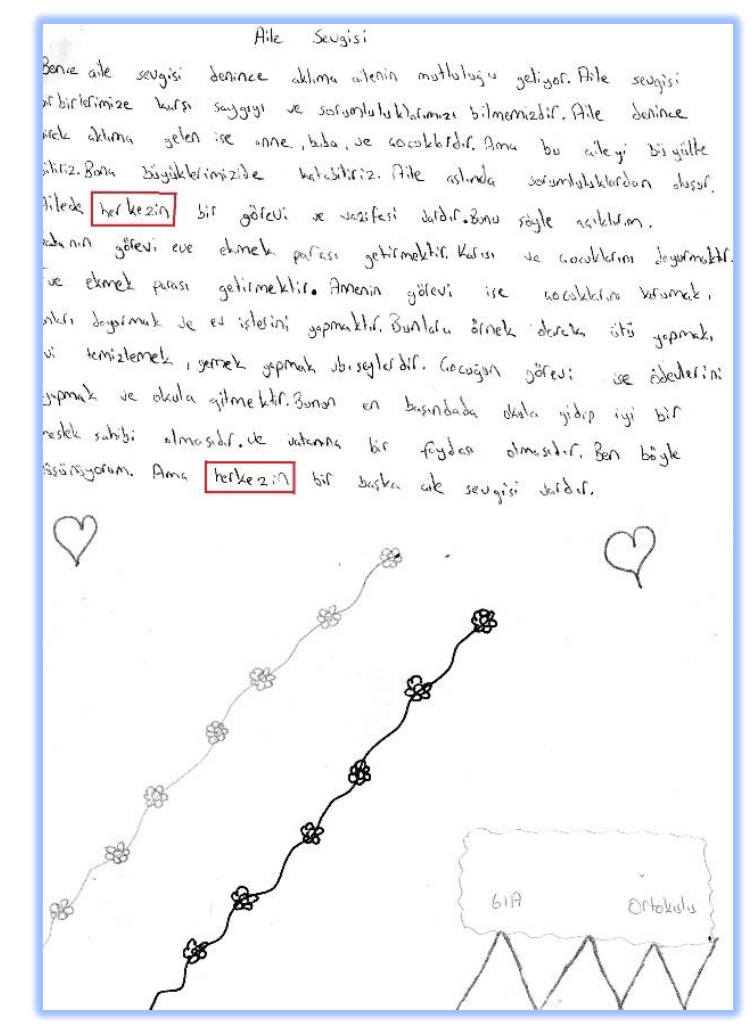

Resim 3. Öğrenci kompozisyonu

Resim 3'te yer alan öğrenci kompozisyonu incelendiğinde, kırmızı dikdörtgenlerle işaretlenmiş olan bölümlerde "herkezin" yazdığı görülmektedir. Tema kapsamında ulaşılan sözcük yazım yanlışları Tablo 4'te sunulmaktadır. 


\section{Ortaokul Altıncı Sınıf Öğrencilerinin Sözcük Düzeyinde Yazım Yanlışlarının İncelenmesi}

\begin{tabular}{ll} 
Tablo 4. Sözcükteki harfi değiştirme \\
\hline Sözcük yanlış yazımı & Sözcük doğru yazımı \\
\hline ayle & aile \\
herkez & herkes \\
ekmeyini & ekmeğini \\
otladırlarmış & otlatırlarmış \\
olmasza & olmazsa \\
çünki & çünkü \\
sahipdir & sahiptir \\
yeyip & yiyip \\
mesala & mesela \\
pisikoloşimiz & psikolojimiz \\
bulamıyacağız & bulamayacağız \\
deyer & değer \\
deyil & değil \\
eyer & eğer \\
nevret & nefret \\
iğliğinizi & iyiliğinizi \\
varlıklarımdım & varlıklarımdır \\
hayatda & hayatta \\
gidemiyecektim & gidemeyecektim \\
\hline &
\end{tabular}

Tablo 4'te sözcükteki harfi değiştirme yanlışları görülmektedir. Bu sözcük yazım yanlışları incelendiğinde sözcük yazımlarında bir harfin yerine başka bir harfin yazıldığı görülmektedir. "ayle" olarak yazım yanlışı 26 defa belirlenmiştir ve en sık görülen sözcük yazım yanlışıdır. "herkez" yazım yanlışı 13 defa tespit edilmiştir. Bunun ardından "mesala" yazım yanlışı gelmektedir. Bu yazım yanlışı ise 5 defa görülmüştür. Sözcükteki harfi değiştirme yazım yanlışı incelendiğinde, s harfinin yerine $z$ harfinin kullanıldığı, ğ harfinin yerine y harfinin kullanıldığı görülmektedir. Öğrenci yazıları incelendiğinde şöyle bir durum tespit edilmiştir. Aynı öğrenci bir cümlede "ayle" olarak yanlış yazdığı bir sözcüğü, farklı bir cümlesinde "aile" olarak doğru bir biçimde yazmaktadır. Ayrıca konuşma sırasındaki sözcük telaffuz kusurlarının yazıya aktarıldığı düşünülmektedir.

\section{Tema 4. Sözcükte Hece Eksikliği}

Ulaşılan dördüncü tema sözcükte hece eksikliği temasıdır. Bu tema kapsamına ortaokul altıncı sınıf öğrencilerinin sözcükte yer alan bir heceyi eksik yazdığı tespit edilmiştir. Konu ile ilgili olarak örnek bir öğrenci kompozisyonu Resim 4'te görülmektedir. 


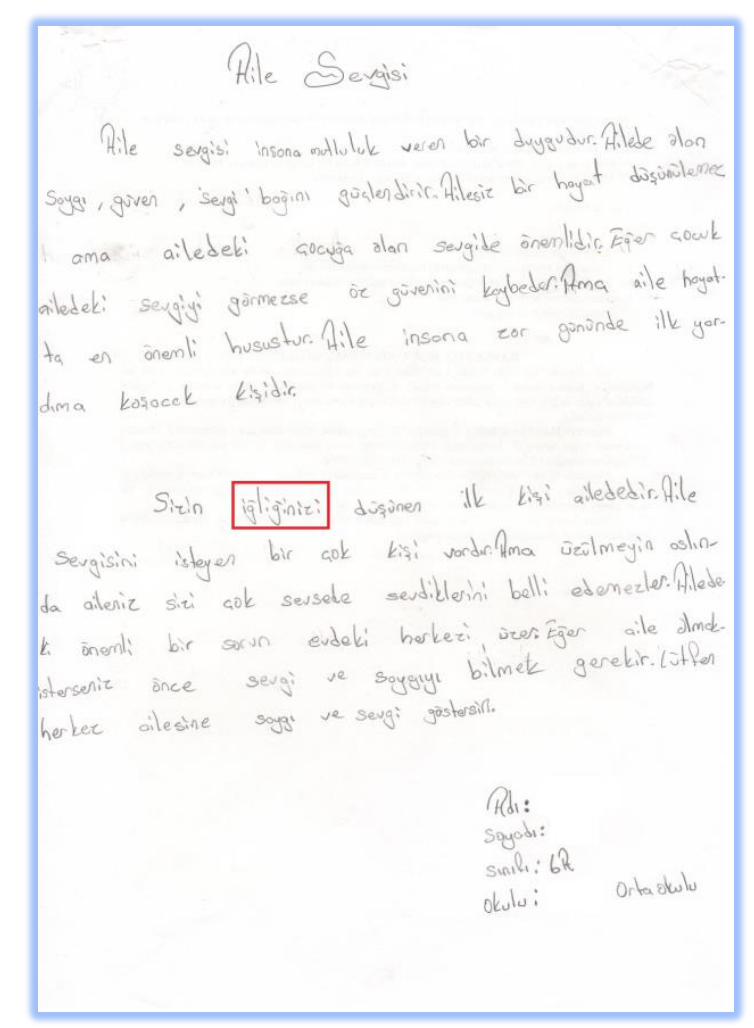

Resim 4. Öğrenci kompozisyonu

Resim 4'te yer alan öğrenci kompozisyonu incelendiğinde, kırmızı dikdörtgen ili belirtilen bölümde, öğrencinin "iğliğinizi” yazdığı görülmektedir. Tema kapsamında ulaşılan sözcük yazım yanlışları Tablo 5'te sunulmaktadır.

Tablo 5. Sözcükte hece eksikliği

\begin{tabular}{ll}
\hline Sözcük yanlış yazımı & Sözcük doğru yazımı \\
\hline istedimi & istediğimi \\
oldunu & olduğunu \\
dedimi & dediğımi \\
acın & ağacın \\
bulamadından & bulamadığından \\
büyünce & büyüyünce \\
nere & nereye \\
sevdim & sevdiğim \\
ailerimizi & ailelerimizi \\
basının & babasının \\
\hline
\end{tabular}

Tablo 5'te sözcükte hece eksikliği yanlışları görülmektedir. Bu sözcük yazım yanlışları incelendiğinde sözcük yazımlarında bir hecenin eksik yazıldığı görülmektedir. Sözcük içerisinde hangi hecenin sıklıkla eksik yazıldığı incelendiğinde ğ harfi dikkat çekmektedir. Bu yazım yanlışının özellikle ğ harfi olan hecelerde yapıldığı görülmektedir.

Tema 5. Sözcükte Büyük ve Küçük Harfin Bir Arada Kullanımı 


\section{Ortaokul Altıncı Sınıf Öğrencilerinin Sözcük Düzeyinde Yazım Yanlışlarının İncelenmesi}

Ulaşılan beşinci tema, sözcükte büyük ve küçük harfin bir arada kullanımı temasıdır. Bu tema kapsamına ortaokul altıncı sınıf öğrencilerinin sözcükte yer alan bir veya birkaç harfi büyük harfle yazdığı tespit edilmiştir. Örnek öğrenci kompozisyon kâğıdı Resim 5' te sunulmaktadır.

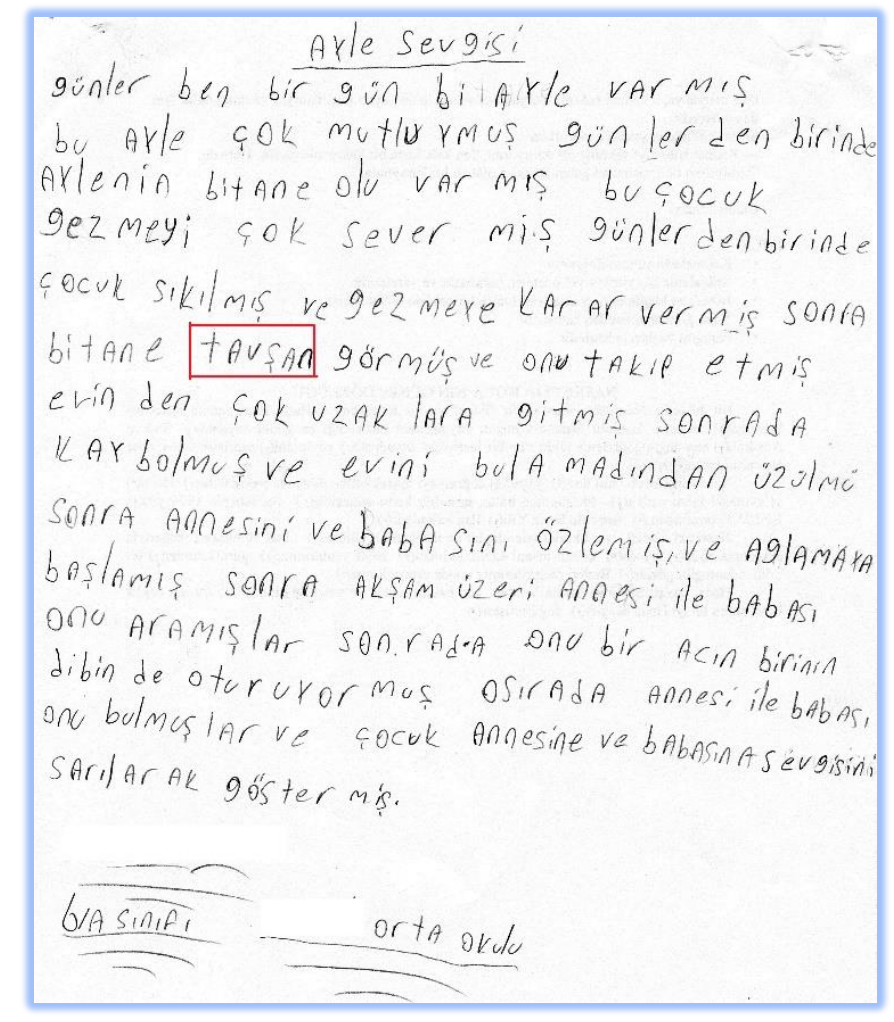

Resim 5. Öğrenci kompozisyonu

Resim 5'te yer alan öğrenci kompozisyonu incelendiğinde, altıncı satır ikinci sıradaki tavşan sözcüğünü görmek mümkündür. Öğrencinin bu sözcüğü "tAvşAn” şeklinde yazdığı görülmektedir. Tema kapsamında ulaşılan sözcük yazım yanlışları Tablo 6'da sunulmaktadır.

Tablo 6. Sözcükte büyük ve küçük harfin bir arada kullanımı

\begin{tabular}{ll}
\hline Sözcük yanlış yazımı & Sözcük doğru yazımı \\
\hline güçlenDirir & güçlendirir \\
eDerler & ederler \\
YıIMAZcan & Yılmazcan \\
tAvşAn & tavşan \\
olurlAr & olurlar \\
babAmız & babamız \\
CAnım & canım \\
çiĞerlerim & ciğerlerim \\
\hline
\end{tabular}

Tablo 6'da sözcükte büyük ve küçük harfin bir arada kullanımı yanlışları görülmektedir. Bu sözcük yazım yanlışları incelendiğinde sözcük yazımlarında bir veya daha fazla harfin büyük harflerle yazıldığı görülmektedir. Öğrencilerin yazıları incelendiğinde, bir öğrencinin yazısında tüm küçük a 
harflerini A olarak yazdığı tespit edilmiştir. Bunun yanı sıra bir diğer öğrenci yazısındaki tüm küçük d harflerini D olarak yazmıştır.

\section{Tema 6. Ayrı Yazılması Gereken Sözcüğg̈ veya Eki Birleştirme}

Ulaşılan altıncı tema, ayrı yazııması gereken sözcüğü veya eki birleştirme temasıdır. Bu tema kapsamına ortaokul altıncı sınıf öğrencilerinin ayrı yazılması gereken sözcükleri veya bir eki birleşik olarak yazdığı tespit edilmiştir. Örnek öğrenci kompozisyon kâğıdı Resim 6'da sunulmaktadır.

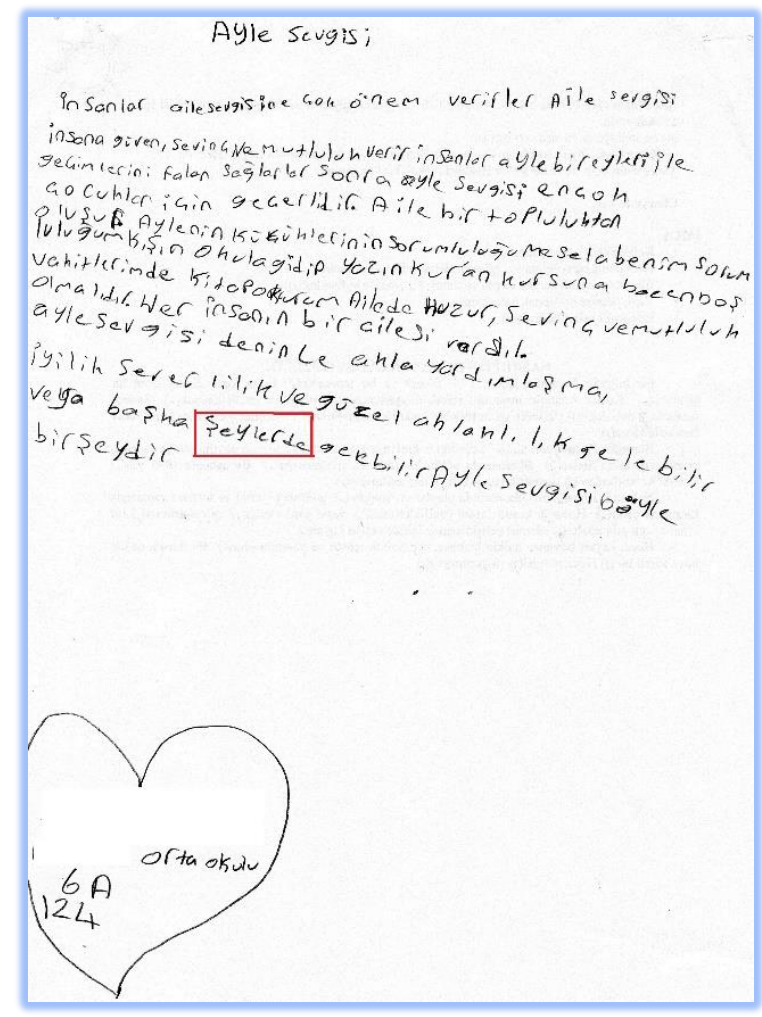

Resim 6. Öğrenci kompozisyonu

Resim $6^{\prime}$ da yer alan öğrenci kompozisyonu incelendiğinde, kırmızı dikdörtgen ile belirtilen bölümde öğrencinin "şeylerde" yazdığı görülmektedir. Oysaki sözcükteki "de" bağlaçtır. Bu nedenle ayrı yazılmalıdır. Tema kapsamında ulaşılan sözcük yazım yanlışları Tablo 7'de sunulmaktadır.

Tablo 7. Ayrı yazılması gereken sözcüğü veya eki birleştirme

\begin{tabular}{ll}
\hline Sözcük yanlış yazımı & Sözcük doğru yazımı \\
\hline bisürü & bir sürü \\
ençok & en çok \\
napardım & ne yapardım \\
okadar & o kadar \\
herşeyimiz & her şeyimiz \\
bişey & bir şey \\
senide & seni de \\
başındada & başında da \\
tabiki & tabi ki \\
heleki & hele ki \\
\hline
\end{tabular}




\begin{tabular}{ll}
\hline iyki & lyi ki \\
anladıki & anladı ki \\
demekki & demek ki \\
üzdümmü & üzdüm mü \\
yaptımmı & yaptım mı \\
seviyormusunuz & seviyor musunuz \\
biçilirmi & biçilir mi \\
sorabilirmiyim & sorabilir miyim \\
\hline
\end{tabular}

Tablo 7'de ayrı yazılması gereken sözcüğü veya eki birleştirme yanlışları görülmektedir. Bu sözcük yazım yanlışları incelendiğinde, ayrı yazılması gereken iki sözcüğün birleşik yazıldığı veya ayrı yazılması gereken ekin birleşik yazıldığı görülmektedir. Bu yazım yanlışının sıklığı incelendiğinde, "napardım" yazım yanlışının ve "okadar" yazım yanlışının dörder defa yapıldığı tespit edilmiştir. Ardından "iyki" şeklinde yapılan yanlışın 3 defa yapıldığı belirlenmiştir. Bu yazım yanlışının alt boyutları incelendiğinde, sözcüklerin birlikte yazıldığı, bağlaç olan "de" ve "ki"nin, soru edatı "mi"nin sözcükle birlikte yazıldığı anlaşılmaktadır.

\section{Tema 7. Sözcükteki Noktalı Harflerin Yazımında Yanlışlık}

Ulaşılan yedinci ve son tema, sözcükteki noktalı harflerin yazımında yanlışlık temasıdır. Bu tema kapsamına ortaokul altıncı sınıf öğrencilerinin ç, ğ, i, ö, ş, ü gibi noktalı harflerin yazımında yanlışlık yaptıkları tespit edilmiştir. Örnek öğrenci kompozisyon kâğıdı Resim 7'de sunulmaktadır.

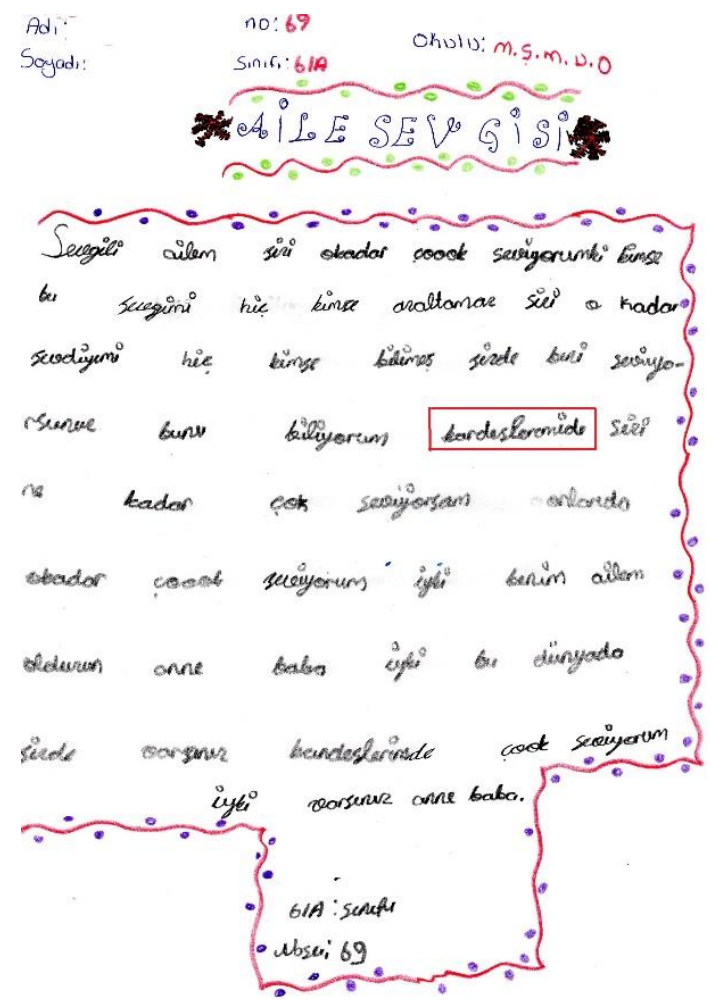

Resim 7. Öğrenci kompozisyonu 
Resim 7'de yer alan öğrenci kompozisyonu incelendiğinde, kırmızı dikdörtgen ile belirtilen bölümde öğrencinin "kardeslerimide" yazdığı görülmektedir. Tema kapsamında ulaşılan sözcük yazım yanlışları Tablo 8'de sunulmaktadır.

Tablo 8. Sözcükteki noktalı harflerin yazımında yanlışık

\begin{tabular}{ll}
\hline Sözcük yanlış yazımı & Sözcük doğru yazımı \\
\hline aglamaya & ağlamaya \\
cünkü & çünkü \\
sevdigini & sevdiğini \\
gunden & günden \\
digeri & diğeri \\
degildir & değildir \\
cigerim & ciğerim \\
eger & eğer \\
sevdigim & sevdiğim \\
yardim & yardım \\
üştümde & üstümde \\
\hline
\end{tabular}

Tablo 8'de sözcükteki noktalı harflerin yazımında yanlışlar görülmektedir. Bu sözcük yazım yanlışları incelendiğinde, sözcükte yer alan noktalı harflerin noktasının yazılmadığı anlaşımaktadır. Örneğin ü harfindeki üstteki iki noktanın yazılmayarak, u şeklinde yazılması gibi. Bunun yanı sıra ğ harfinde üstte yer alan eğik çizginin yer almadığı örnekler yer almaktadır. Tabloda yer alan son iki sözcük incelendiği zaman farklı bir durumla karşılaşılmaktadır. "yardim" sözcüğünde yer alan । harfinin üzerine fazladan nokta konularak i harfi olarak yazıldığı görülmektedir. Ayrıca "üştümde" yazımında s harfinin altına nokta konularak ş harfi olarak yazıldığı dikkat çekmektedir.

\section{Tartışma, Sonuç ve Öneriler}

Yapılan araştırma neticesinde, ortaokul altıncı sınıf öğrencilerinin sözcük yazım yanlışları konusunda yedi adet sonuca ulaşılmıştır. Ulaşılan bu sonuçlar şunlardır:

1. Sözcüğe fazladan harf ekleme.

2. Sözcükte harf eksikliği.

3. Sözcükteki harfi değiştirme.

4. Sözcükte hece eksikliği.

5. Sözcükte büyük ve küçük harfin bir arada kullanımı.

6. Ayrı yazılması gereken sözcüğü veya eki birleştirme.

7. Sözcükteki noktalı harflerin yazımında yanlışıı. 


\section{Ortaokul Altıncı Sınıf Öğrencilerinin Sözcük Düzeyinde Yazım Yanlışlarının İncelenmesi}

Araştırma sonucunda ulaşılan ilk sonuç, ortaokul altıncı sınıf öğrencilerinin sözcük yazımında sözcüğe fazladan harf ekleme yapmalarıdır. Öğrencilerin sözcük yazımında fazladan harf ekleme durumu çok düşük seviyededir. Araştırma sonucuyla benzerlik gösterecek şekilde Calp (2013) tarafından yapılan araştırma sonucunda, ilkokul dördüncü sınıf öğrencisinin sözcük yazımlarında, sözcük içinde harf ekleme yaptığı belirtilmiştir. Bunun yanı sıra Akkaya (2013) tarafından yapılan araştırma sonucunda ortaokul altıncı sınıf öğrencilerinin sözcük yazımında ses eklemeleri yaptığı vurgulanmıştır. İlgili araştırma sonuçlarıyla karşılaştııılı̆̆ı zaman, ilköğretim seviyesinde öğrencilerin sözcüklere harf ekleme yapabildikleri anlaşılmaktadır.

Araştırma sonucunda ulaşılan ikinci sonuç, ortaokul altıncı sınıf öğrencilerinin sözcük yazımında sözcükte harf eksikliği yapmalarıdır. Bu sonuç kapsamına ortaokul altıncı sınıf öğrencilerinin sözcükte bir harfi eksik yazdığı tespit edilmiştir. Bu yazım yanlışları incelendiğinde, konuşma sırasında sözcüklerde eksik harf söyleme durumu akla gelmektedir. Örneğin konuşmada kullanılan "dakka" sözcüğünün yazıya aynen geçirildiği düşünülmektedir. Araştırma sonucuyla benzerlik gösterecek şekilde Kurtlu ve Korucu (2015) tarafından yapılan araştırma sonucunda, altıncı sınıf öğrencilerinin sözcük yazımlarında harf eksikliği yaptığı belirtilmiştir. Bunun yanı sıra Calp (2013) tarafından yapılan araştırma sonucunda ilkokul dördüncü sınıf öğrencisinin sözcük yazımında, sözcük içindeki bazı harfleri atladığı tespit edilmiştir. Ayrıca ilanbey ve Can (2016) tarafından yapılan araştırma sonucunda ortaokul öğrencilerinin yazılarında olum (oğlum), Saol (sağ ol) şeklinde yazım yanlışları yaptıkları vurgulanmıştır. Illgili araştırma sonuçları ile birlikte durum değerlendirildiğinde, konuşma sırasında yapılan, sözcüğün eksik sesle söylenme durumunun yazıya olduğu gibi yansıdığı anlaşıımaktadır.

Araştırma sonucunda ulaşılan üçüncü sonuç, ortaokul altıncı sınıf öğrencilerinin sözcük yazımında sözcükteki harfi değiştirmesidir. Bu sonuç kapsamına ortaokul altıncı sınıf öğrencilerinin sözcükte yer alan bir harfi, başka bir harfle değiştirerek yazdığı tespit edilmiştir. "ayle", "herkez", "mesala" en sık görülen sözcük yazım yanlışlarıdır. Sözcükteki harfi değiştirme yazım yanlışı incelendiğinde, s harfinin yerine $z$ harfinin kullanıldığı, ğ harfinin yerine y harfinin kullanıldığı tespit edilmiştir. Ayrıca konuşma sırasındaki sözcük telaffuz kusurlarının yazıya aktarıldığı düşünülmektedir. Araştırma sonucuyla benzerlik gösterecek şekilde Kurtlu ve Korucu (2015) tarafından yapılan araştırma sonucunda, altıncı sınıf öğrencilerinin sözcük yazımlarında harfi yanlış yazdıkları belirtilmiştir. Bunun yanı sıra Calp (2013) tarafından yapılan araştırma sonucunda ilkokul dördüncü sınıf öğrencisinin sözcük yazımında, " $b$ " ile " $d$ " harflerini, " $s$ " ile " $z$ " harflerini karıştırdığı tespit edilmiştir. Ayrıca Hamzadayı ve Çetinkaya (2013) tarafından yapılan araştırmada ilkokul beşinci sınıf öğrencilerinin ses olayları (yumuşama ve sertleşme) konularında yanlışlıklar yaptıkları belirtilmiştir. Ayrıca Ilanbey ve Can (2016) tarafından yapılan araştırma sonucunda ortaokul öğrencilerinin 
yazılarında aktarıyım (aktarayım), dayanamıyarak (dayanamayarak) şeklinde yazım yanlışları yaptıkları tespit edilmiştir. Beyreli, Çetindağ ve Celepoğlu (2015, s. 19) bu yazım yanlışını, konuşma dilindeki sözcük söylemlerinin yazıya geçirilmesindeki yanlışıık olarak dile getirmektedir.

Araştırma sonucunda ulaşılan dördüncü sonuç, ortaokul altıncı sınıf öğrencilerinin sözcük yazımında hece eksikliği yapmalarıdır. Bu tema kapsamına ortaokul altıncı sınıf öğrencilerinin sözcükte yer alan bir heceyi eksik yazdığı tespit edilmiştir. Sözcük içerisinde hangi hecenin sıklıkla eksik yazıldığı incelendiğinde ğ harfi dikkat çekmektedir. Bu yazım yanlışının özellikle ğ harfi olan hecelerde yapıldığı görülmektedir. Sözcükteki hece eksikliğinin yapılma nedeni olarak, konuşma sırasında sözcüğün eksik seslerle söylenmesinin neden olduğu düşünülmektedir. Araştırma sonucuyla benzerlik gösterecek şekilde Illanbey ve Can (2016) tarafından yapılan araştırma sonucunda ortaokul öğrencilerinin yazılarında içecen (içeceksin) şeklinde yazım yanlışları yaptıkları tespit edilmiştir. İlanbey ve Can (2016) bu durumu ağız kullanımı ile ilişkilendirmektedir.

Araştırma sonucunda ulaşılan beşinci sonuç, ortaokul altıncı sınıf öğrencilerinin sözcük yazımında sözcükte büyük ve küçük harfi bir arada kullanmalarıdır. Bu sonuç kapsamına ortaokul altıncı sınıf öğrencilerinin sözcükte yer alan bir veya birkaç harfi büyük harfle yazdığı tespit edilmiştir. Araştırma sonucuyla benzerlik gösterecek şekilde Kurtlu ve Korucu (2015) tarafından yapılan araştırma sonucunda, altıncı sınıf öğrencilerinin sözcük yazımlarında büyük harf kullanımı konusunda yanlışlar yaptığı belirtilmiştir. Bunun yanı sıra Calp (2013) tarafından yapılan araştırma sonucunda ilkokul dördüncü sınıf öğrencisinin sözcük yazımında, sözcük içinde bazen büyük, bazen küçük harf kullandığı tespit edilmiştir. Ayrıca Hamzadayı ve Çetinkaya (2013) tarafından yapılan araştırmada ilkokul beşinci sınıf öğrencilerinin büyük/küçük harf yazım yanlışları yaptıkları belirtilmiştir. Altıncı sınıf seviyesindeki bir öğrencinin küçük harflerle yazılması gereken bir sözcüğün içerisinde büyük harfler kullanması önemli bir sorundur. Bu durum öğrencinin harflerin büyük ve küçük şekillerini zihninde yerleştiremediğini göstermektedir.

Araştırma sonucunda ulaşılan altıncı sonuç, ortaokul altıncı sınıf öğrencilerinin sözcük yazımında ayrı yazılması gereken sözcüğü veya eki birleştirmeleridir. "napardım”, "okadar", "iyki” en sık rastlanan sözcük yazım yanlışları olmuştur. Ayrı yazılması gereken sözcüklerin bir arada yazılması yazım hatasında akla ilk olarak konuşmada yapılan hatalar gelmektedir. Bağlaçların ve soru ekinin yazımında ise, öğrencinin bu bilgiyi unuttuğu veya uygulama eksikliği akla gelmektedir. Araştırma sonucuyla benzerlik gösterecek şekilde Kurtlu ve Korucu (2015) tarafından yapılan araştırma sonucunda, altıncı sınıf öğrencilerinin sözcük yazımlarında bağlaç olan de, bağlaç olan ki, soru eki mi, sözcüklerin birleşik yazııması konularında sıkıntılar yaşadıkları vurgulanmıştır. Bunun yanı sıra Akkaya (2013) tarafından yapılan araştırma sonucunda ortaokul altıncı sınıf öğrencilerinin bağlaç olan "da, de"nin yazılışında, bağlaç olan "ki"nin yazılışında ve soru eki “mı, mi, mu, mü"nün yazıışında 


\section{Ortaokul Altıncı Sınıf Öğrencilerinin Sözcük Düzeyinde Yazım Yanlışlarının İncelenmesi}

yanlışlıklar yaptığı vurgulanmıştır. Ayrıca Hamzadayı ve Çetinkaya (2013) tarafından yapılan araştırmada ilkokul beşinci sınıf öğrencilerinin soru eki (mı, mi, mu, mü) yazım yanlışları; da, de bağlacı ile da, de ekini karıştırma ki bağlacı ile ki ekini karıştırma gibi yazım yanlışları yaptıkları belirtilmiştir.

Araştırma sonucunda ulaşılan yedinci ve son sonuç, ortaokul altıncı sınıf öğrencilerinin sözcük yazımında sözcükteki noktalı harflerin yazımında yanlışlık yapmalarıdır. Bu tema kapsamında ortaokul altıncı sınıf öğrencilerinin ç, ğ, i, ö, ş, ü gibi noktalı harflerin yazımında yanlışlık yaptıkları tespit edilmiştir. Öğrenci "ı" harfi yazması gereken yerde nokta koyarak "i" harfi şeklinde yazabilmektedir. Bunun yanı sıra "ş" harfi ile yazması gereken yerde "s" şeklinde yazabilmektedir. Harfin noktası eksik olduğu zaman öğrenci unutmuş olabilir. Ancak nokta olmaması gereken "ı" harfi bu duruma uymamaktadır. Öğrenci "ı" harfine fazladan nokta koyup "i" şeklinde yazabilmektedir. Araştırma sonucuyla benzerlik gösterecek şekilde Calp (2013) tarafından yapılan araştırma sonucunda, ilkokul dördüncü sınıf öğrencisinin sözcük yazımlarında, sözcükteki harflerin nokta ve kuşaklarını sözcüğü yazdıktan sonra koymadığı belirtilmiştir.

Yapılan araştırma sonuçları ile ilgili araştırma sonuçları incelendiğinde, mevcut ortaokul altıncı sınıf öğrencilerinin geçmişteki yazım yanlışları ile aynı yazım yanlışlarını gösterdikleri anlaşılmaktadır. Sözcük yazım yanlışlarının ana nedeni olarak öncelikle, konuşmadaki sözcük söylem hatalarının yazıya yansıdığı düşünülmektedir. Bunun yanı sıra ayrı yazılan eklerin ve bağlaçların yazımında sıkıntılar olduğu görülmektedir. Bu durumun ana nedeni olarak, bilgi ve uygulama eksikliğinin olduğu düşünülmektedir.

Araştırma sonuçları kapsamında şu önerilerde bulunulmuştur:

1. Ortaokul altıncı sınıf öğrencilerinin konuşmadaki yanlışları yazıya aktardıkları belirlenmiştir. Bu nedenle, öncelikle Türkçe öğretmenlerinin daha sonra diğer branş öğretmenlerinin, ailelerin öğrencilerin konuşmadaki yanlışları düzeltmeleri gerekmektedir.

2. Sözcük yazım yanlışları incelendiğinde "herkes", "mesela", "aile" gibi sözcüklerin öğrenciler tarafından tam olarak öğrenilemediği anlaşılmaktadır. Bu gibi kelimelerin yazımına yönelik fazladan çalışmalar yapılması önerilmektedir.

3. Sözcük yazım hatalarının azaltılmasına yönelik olarak, dikte çalışmalarının artırılması önerilmektedir.

4. Bağlaç ve eklerin yazımındaki sıkıntılara yönelik olarak, yazım ve düzeltme çalışmalarının artırılması önerilmektedir. 
5. Öğrencilerin yazma çalışmaları sonrasında Türkçe öğretmeninin yazılı metinler üzerinde düzeltmeleri belirtmesi ve bu düzeltmelerin öğrencilere gösterilmesi gerekmektedir. Yazım yanlışları konusu bağlamında bu uygulamanın sıklaştırılması önerilmektedir.

\section{Kaynaklar}

Akkaya, A. (2013). 6. sınıf öğrencilerinin yazım yanlışları sıklı̆ı ve yazım yanlışlarının nedenlerine ilişkin öğretmen görüşleri. Electronic Turkish Studies, 8 (4), 33-52.

Aktaş, Ş. ve Gündüz, O. (2002). Yazılı ve sözlü anlatım (3. Baskı). Ankara: Akçağ Basım Yayım Pazarlama A.Ş.

Akyol, H. (2006). Türkçe ilk okuma yazma öğretimi (5. Baskı). Ankara: Pegem A Yayıncılık.

Alperen, N. (2001). Türkçe okuma ve yazma eğitimi rehberi (7. Baskı). Ankara: Alperen Yayınları.

Beyreli, L., Çetindağ, Z. ve Celepoğlu, A. (2015). Yazıı ve sözlü anlatım (8. Baskı). Ankara: Pegem Akademi.

Bussmann, H. (2002). Lexikon der sprachwissenschaft, dritte, aktualisierte und erweiterte auflage, Stuttgart: Kröner.

Calp, M. (2013). Yazma problemi olan bir öğrenciye bitişik eğik yazı öğretimi (bir eylem araştırması). EInternational Journal of Educational Research, 4 (1), 1-28.

Creswell, J. W. (2012). Educational research: planning, conducting, and evaluating quantitative and qualitative research (4th ed.). Boston: Pearson Education, Inc.

Creswell, J. W. (2013). Araştırma deseni: nitel, nicel ve karma yöntem yaklaşımları, (Çev. Ed: S. B. Demir). İstanbul: Eğiten Kitap.

Çelik, H. ve Ekşi, H. (2015). Nitel desenler: gömülü teori. İstanbul: EDAM Yayınları.

Glesne, C. (2012). Nitel araştırmaya giriş. (A. Ersoy ve P. Yalçınoğlu, Çev. Ed.). Ankara: Anı Yayıncılık.

Göçer, A. (2015). Türkçe dersi metin işleme sürecinde bağlam temelli sözcük öğretimi ve etkin sözcük dağarcığı oluşturmadaki işlevi. Ana Dili Eğitimi Dergisi, 3 (1), 48-63.

Hamzadayı, E. ve Çetinkaya, G. (2013). Dikte uygulamalarının 5. sınıf öğrencilerinin yazım ve noktalama kurallarını uygulama becerilerine etkisi. Mersin Üniversitesi Eğitim Fakültesi Dergisi, 9 (3), 133-143.

ilanbey, Ö. ve Can, R. (2016). Ortaokul öğrencilerinin yazılı anlatımlarında konuşma dili unsurlarının incelenmesi. Zeitschrıft Für Dıe Welt Der Türken / Journal Of World Of Turks, 8 (2), 241-256.

Johnson, D. ve Johnson, B. (2005). Vocabulary Development. S. J. Farenga ve D. Ness (Ed.), Encyclopedia of education and human development. New York: M.E. Sharpe, Inc.

Karatay, H. (2007). Kelime öğretimi. GÜ, Gazi Eğitim Fakültesi Dergisi, 27 (1), 141-153.

Kurtlu, Y. ve Korucu, S. (2015). Altıncı sınıf öğrencilerin dik temel ve bitişik eğik yazılarının yazım yanlışları ve noktalama işaretleri bakımından karşılaştııılması. Erzincan Üniversitesi Sosyal Bilimler Enstitüsü Dergisi, $9(2), 167-190$.

Kurudayıoğlu, M. ve Karadağ, Ö. (2005). Kelime hazinesi çalışmaları açısından kelime kavramı üzerine bir değerlendirme. Gazi Üniversitesi Gazi Eğitim Fakültesi Dergisi, 25 (2), 293-307.

Mayor, M. (2009). Longman dictionary of contemporary English. Essex: Pearson Education Limited.

Merriam, S. B. (2013). Nitel araştırma desen ve uygulama için bir rehber. Selahattin Turan (Çev. Ed.). Ankara: Nobel Akademik Yayıncılık.

Miles, B. ve Huberman, M. (2015). Genişletilmiş bir kaynak kitap: nitel veri analizi (Çev. Ed.: Sadegül Akbaba Altun ve Ali Ersoy). Ankara: Pegem Akademi. 


\section{Ortaokul Altıncı Sınıf Öğrencilerinin Sözcük Düzeyinde Yazım Yanlışlarının İncelenmesi}

Özbay, M. ve Melanlıoğlu, A. G. D. (2008). Türkçe eğitiminde kelime hazinesinin önemi. Yüzüncü Yıl Üniversitesi Eğitim Fakültesi Dergisi, 5 (1), 30-45.

Patton, M. Q. (2014). Nitel araştırma ve değerlendirme yöntemleri (3. Baskıdan Çeviri). (Çev. Ed.: Mesut Bütün, Selçuk Beşir Demir). Ankara: Pegem Akademi.

Sönmez, V. ve Alacapınar, F. G. (2011). Örneklendirilmiş bilimsel araştırma yöntemleri. Ankara: Anı Yayıncılık.

Temple, C. ve Gillet, J. W. (1989). Language arts: learning processes and teaching practices (2nd ed.) London: Scott, Foresman and Company.

Yıldırım, A. ve Şimşek, H. (2006). Sosyal bilimlerde nitel araştırma yöntemleri (6. baskı). Ankara: Seçkin Yayıncılık.

\section{Extended Abstract}

Introduction

Spelling mistakes can be seen in all educational levels. Writing skills are aimed to be developed starting from the first grade in the primary school. As the writing skills improve, word spelling mistakes will decrease. In the introduction part of this research, the concept of word then the word spelling mistake are explained. The aim of this study is to examine the word spelling mistakes of the sixth grade students in the secondary school. The research is important in determining the spelling mistakes of the sixth grade students on a word level. It is thought that the research will primarily contribute to Turkish teachers, Turkish education and writing skills education in specific. This research is limited to words related to family topic.

\section{Method}

The research was carried out document analysis which is a qualitative research method. Document analysis method was used because the students' writings were examined in order to examine the spelling mistakes of the sixth grade students in the secondary school. In the determination of the study group, convenience sampling was used from purposeful sampling methods. Within the scope of convenience sampling, 163 students studying in the sixth grade in a state secondary school in Yozgat were studied. All of the students have average intelligence level and there are no students who attend special education courses. 85 of the students are male and 78 are female. With the help of an opinion of faculty member, it was decided that the participants would be asked to write a composition. Upon the consultation to the Turkish teacher, the subject of composition was decided to be family love. Data were collected in May 2018. In the Turkish language lessons, the sixth grade students wrote a composition about family love. The researcher was present with the Turkish teacher at the data collection stage. The task of instructing on writing the composition and the title to the students was the Turkish teacher's responsibility. The researcher handed out and collected the papers. Content analysis technique was used in the analysis of the data.

\section{Result and Discussion}

As a result of the research, seven word spelling mistakes of the sixth grade students were found. These results are as follow:

1. Add extra letters to the word.

2. Lack of letters in the word.

3. Change the letter in the word.

4. Lack of syllables in the word.

5. Using of upper and lower case.

6. Merge the word or affix which needs to be written separately.

7. Mistake in the spelling of dotted letters in the word.

As the main reason of the word spelling mistakes, it is thought that the mistakes in the speech are reflected in the writing. The main reason for this situation is the lack of knowledge and application. 